\title{
سمات الفن الهزلي فى الحضارات القديمة وآثره على التصوير الحديث"
}

\author{
إعداد

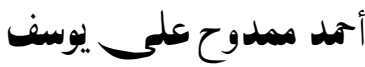 \\ موظف بمعمل المالتي ميديا ( Multimedia Lab ) \\ بكلية الحاسبات والمعلومات - جامعة اسيوط \\ تحت إشراف
}

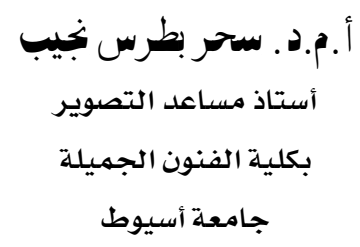
أ. م.ه. محمد ثابت بداركي
أستاذ مساعد التصوير ووكيل كلية الفنون الجميلة لشئون التعليم والطلاب
جامعة أسيوط

مجلة بحوث التربية النوعية ـ جامعة المنصورة

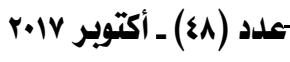

$$
\begin{aligned}
& \text { بحث مستل من رسالة ماجستير }
\end{aligned}
$$




\section{سمات الفن الهزلي فى الحضارات القديمة وآثره على التصوير الحديث}

$$
\begin{aligned}
& \text { إعداد } \\
& \text { * أحمد ممدوحعلكيوسفت } \\
& \text { أ. . .د . سحر بطرس بجيب **** } \\
& \text { أ. .د ـ محمد ثابت بداري }
\end{aligned}
$$

unil|

ريط علماء النفس والشعراء بين سبل الإدراك ومحاور الحس الهزلية بلدء من الفكاهة والكوميديا والهزل وتأثر فنانون من مختلف الحضارات القديهة كالفن الهزلي وفن الكاريكاتير

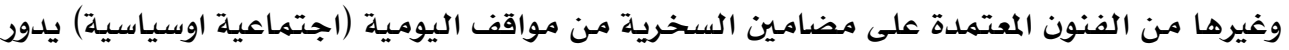

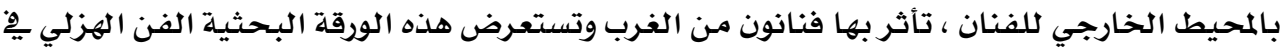

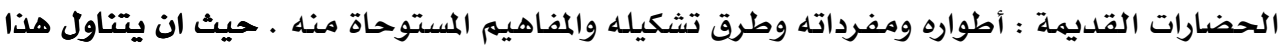

البحث بالدراسة والتحليل النقاط التالية :

$$
\begin{aligned}
& \text { 1- مقدمـة ( مشكلة البحث - أهداف البحث - أهميتها - حدودها - المنهج المتبع ) . }
\end{aligned}
$$

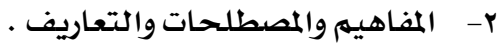

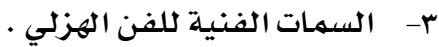

$$
\begin{aligned}
& \text { ع- تطور التصوير الهزلي فى الفنون القديمة . } \\
& \text { • • الفن الهزبي عند قدماء المصريين . }
\end{aligned}
$$

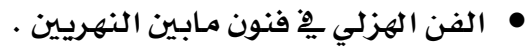

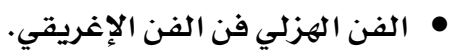

$$
\begin{aligned}
& \text { ه- نماذج فنانين من الغرب تأثروا من فنون الحضارات القديمة فى أعما لهم التصويرية . } \\
& \text { 7- أبتائج وتوصيات. }
\end{aligned}
$$

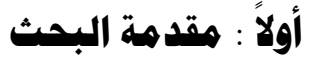

الضحك والهزل هو شكل مـن أشـكال التعبير الصريح عن التسلية والمرح، ومسشاعر أخـري

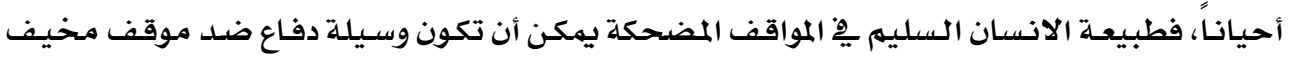

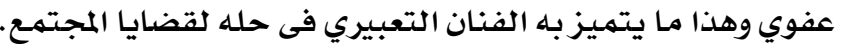

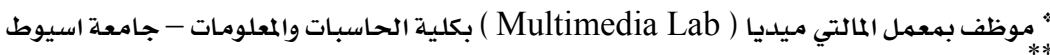

أستاذ مساعد التصوير ووكيل كلية الفنون الجميلة لشئون التعليم والطلاب جامعة أسيوط أستاذ مساعد التصوير بكلية الفنون الجميلة جامعة أسيوط 


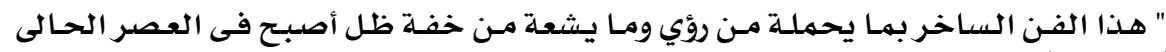

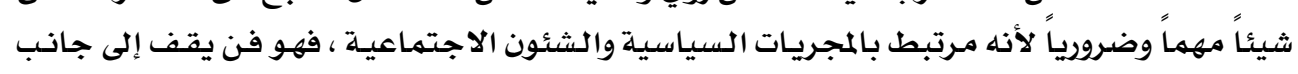

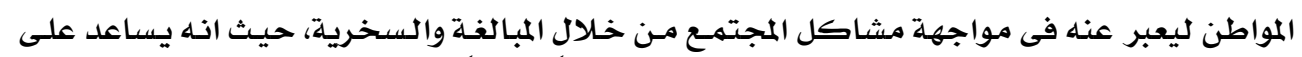

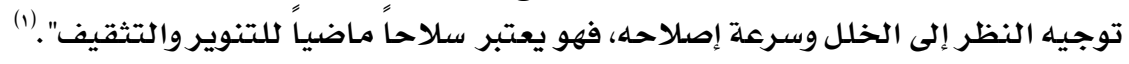

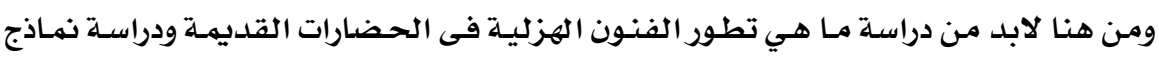

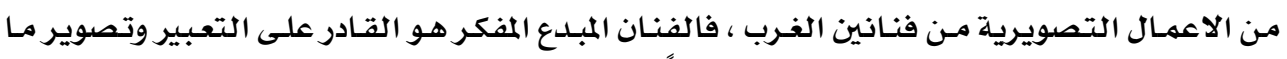

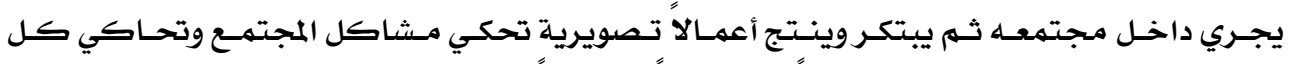

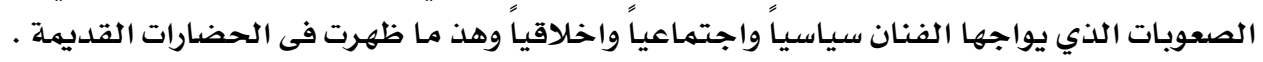

تمثلت مشكلة البحث فى التساؤل الآتي : ما هي امكانية الاستفادة من سمات الفن الهزبي

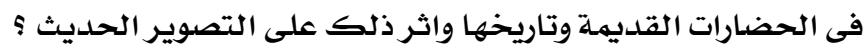

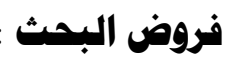

هناك علاقة إيجابية بين أستفادة فنانين المدارس الحديثة من الفن الهزلي فى العصور

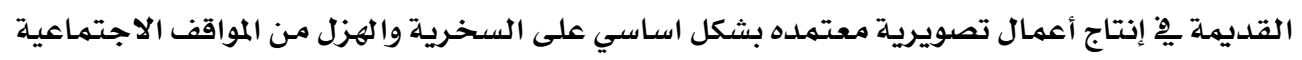
والسياسية المحيط بالفنان إنتاج أعهال تصوير

- التعرف على مفهوم التعبيريه الهزلية والفرق بينه وبين الكاريكاتير (الفن الصحفي) -

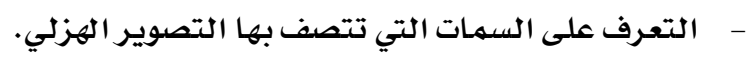

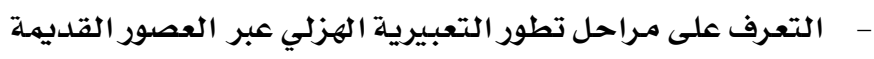

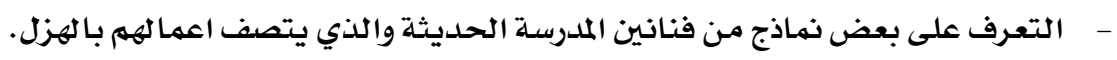

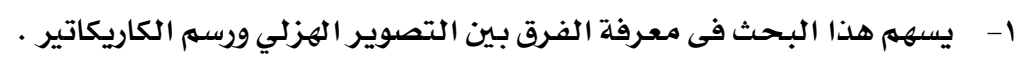

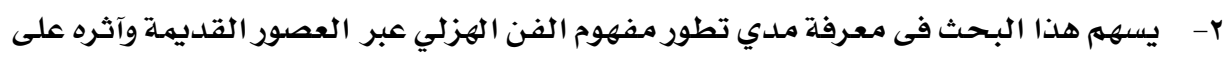

لوحات تصويرية حديثة .

(1) عادل مصطفى كامل : الكاريكاتير فى مصر، سلسلة الفنون، الهيئة المصرية العامة للكتاب، مكتبة الاسره 9 ..r، صد9. 
ا ـ دراسـة تاريخ التصوير الهزلى فى العصور القديمة (فى مصر وبـلاد مـابين النهرين واليونانيون)

$$
\text { وبعض المصورين يِّ الغرب . }
$$

ثانياً : حدود زمانية :

ا ـ دراسة الفنون الهزلية عبر العصور القديمة .

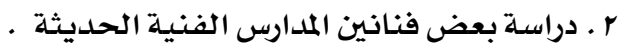

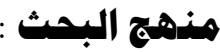

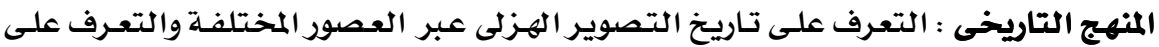

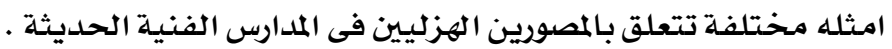

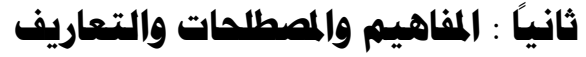

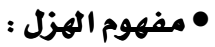

" قال تعالى فى سورة الطارق (وما هو بالهزل(ع ()) معني الاية هنا انه ليس بباطل ولكنـه هـو

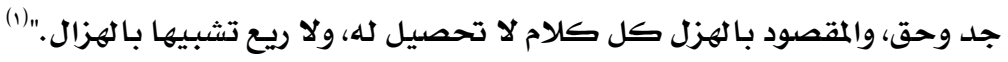

والهزل عند العرب هو " نقيض الجد، هزل يهزل هزلاً، قال (الكميت)" :

أرانا على حب الحياة وطولها تجد بنا فِ فكل يوم ونهزل

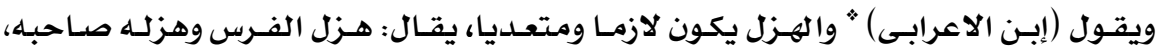

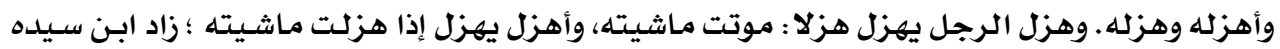

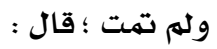

يا أم عبد الله لا تستعجلي ورفعي ذلاذل المرجل

إني إذا مر زمان معضل يهزل ومن يهزل ومن لا يهزل

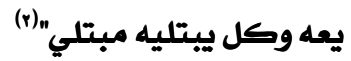

(1) http://www.almaany.com/quran/86/14/3/\#.V14QOr-6bDc

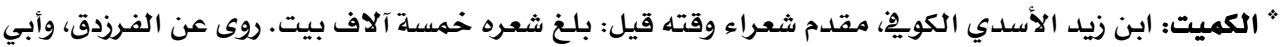

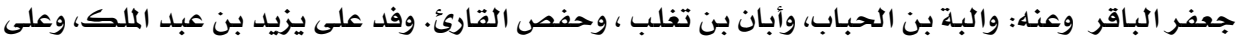

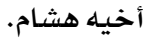

" إبن الاعرابى: إمام اللغة أبو عبد الله، محمد بن زياد بن الأعرابي الهاشمي مولاهم الأحول النسابة، ولد

(2) بالكوفة سنة خمسين ومائة. 


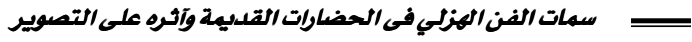 \\ ثالثًا : هفهوم الكاريكاتير (الرسم الصهفى):}

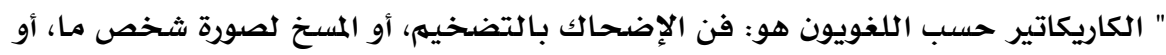

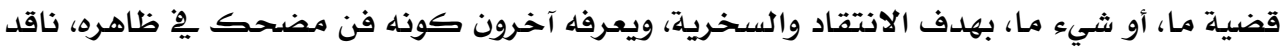

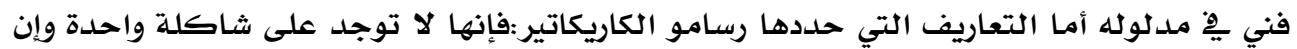

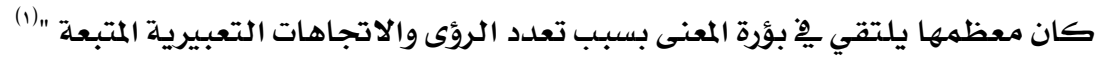

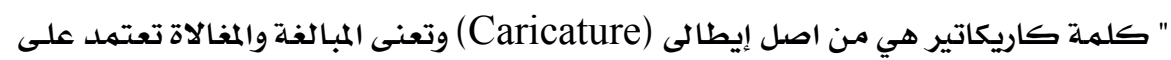

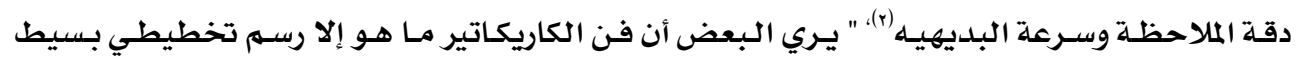

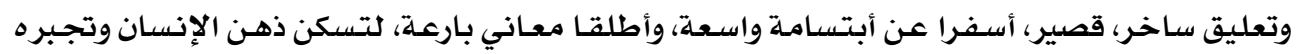

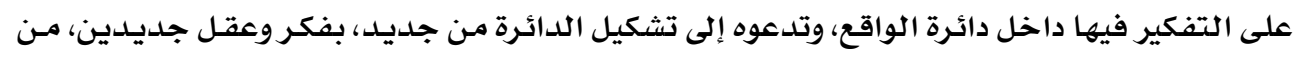

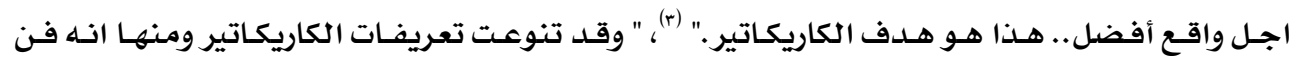

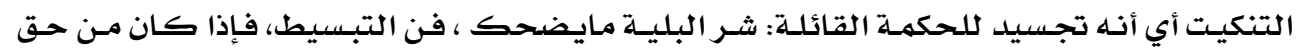

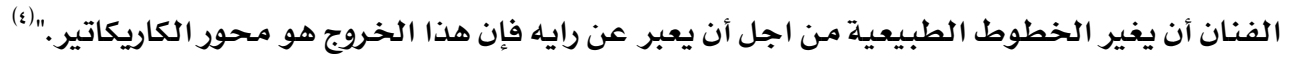

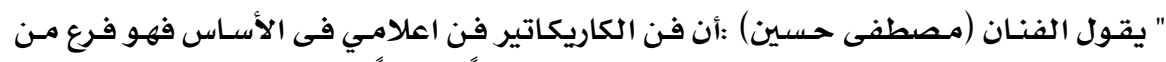

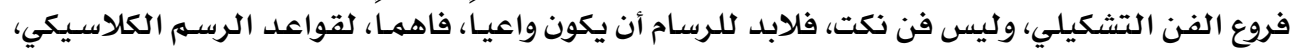

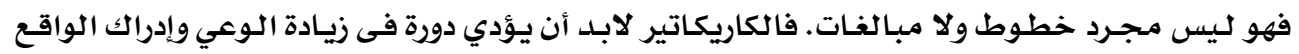

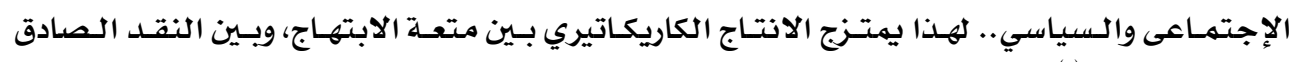

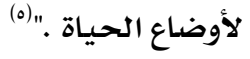

\section{• مفهوم السخرية فى الفن:}

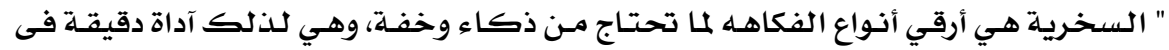

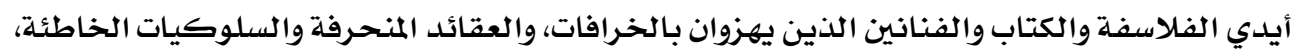

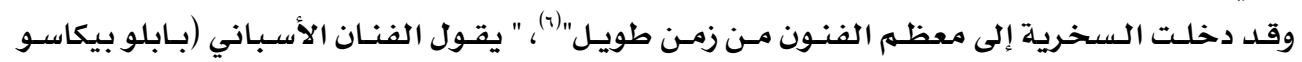

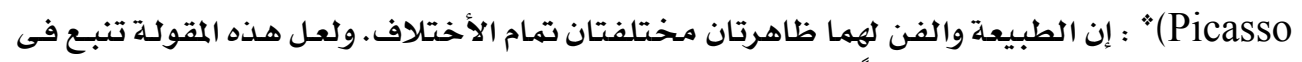

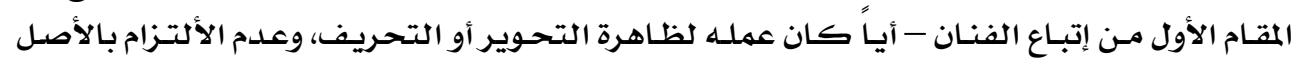

${ }^{(1)}$ https://www.ward2u.com/showthread.php?t=22836

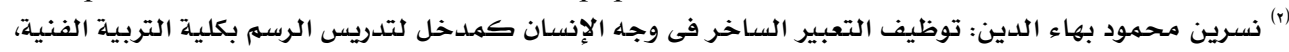

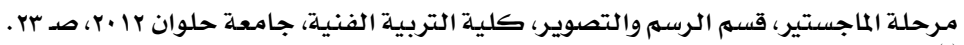

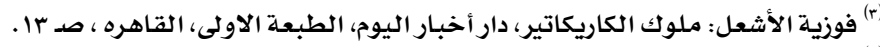

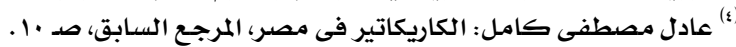

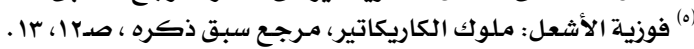

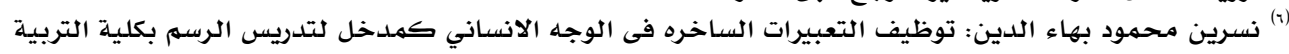

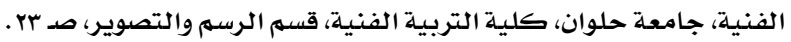

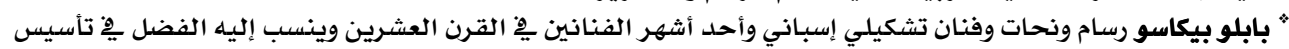

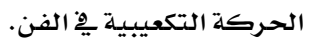


مجلة بحوث التربية النوعية - علد 11 - أكتوبر r.lV

الطبيعى أو الواقعى للأشياء، فالفنان قد يبالتغ أو يضيف أو يحزف أو حتى يبسط، دون إلتزام كاملـ

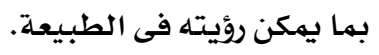

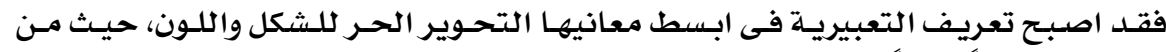

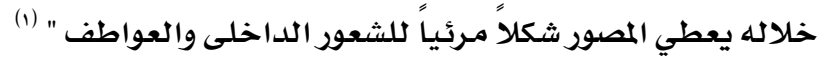

ويقـول (عبـاس محمـود العقـاد) في كتـاب (حجـا الضـاحك المضحك) " أن هنـاك أنواعـا

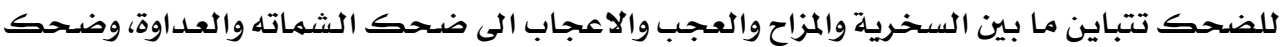

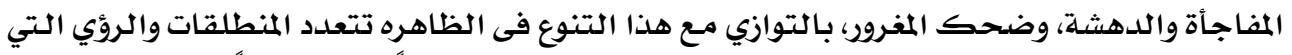

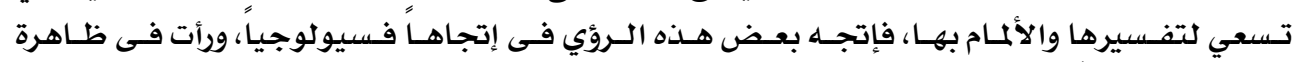

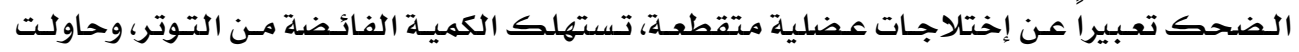

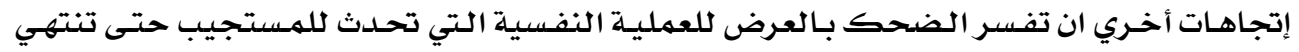

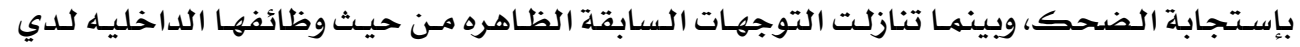

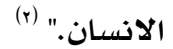

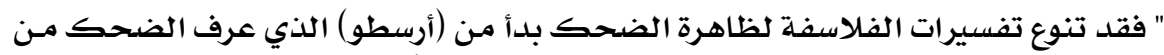

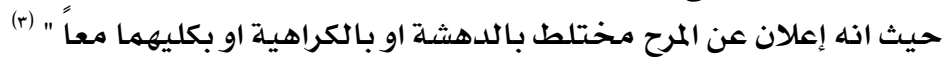

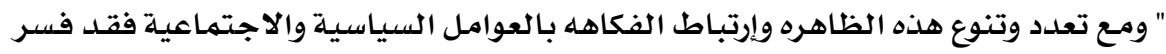

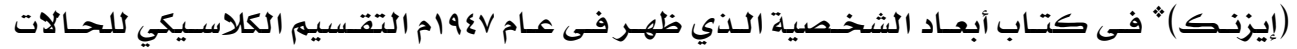

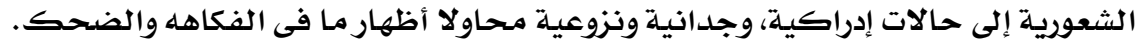

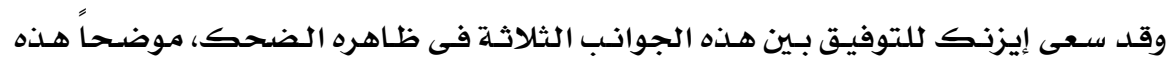

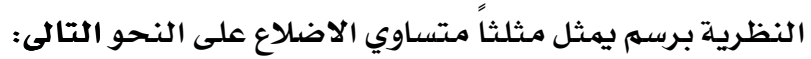

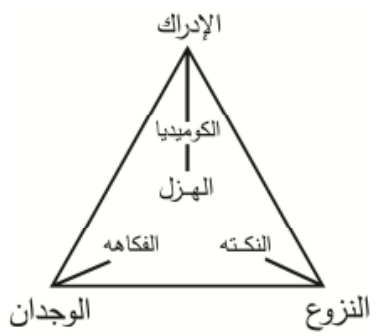

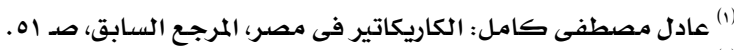

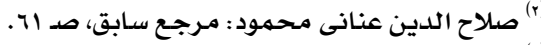

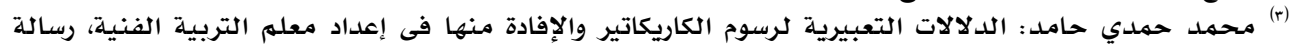

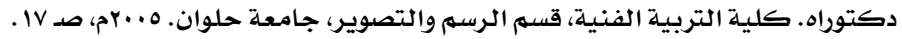

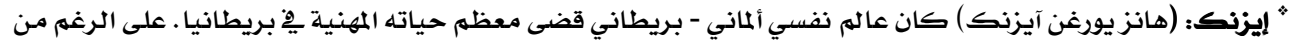

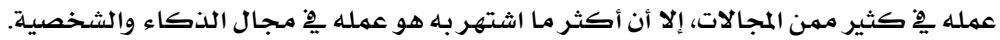
https://ar.wikipedia.org/wiki/\%D9\%87\%D8\%A7\%D9\%86\%D8\%B2_\%D8\%A2\%D9\%8A $\%$ D8\%B2\%D9\%86\%D9\%83 


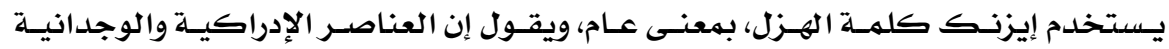

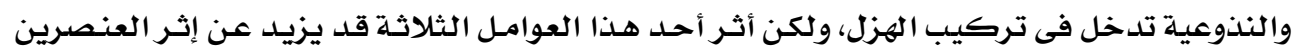
الآخرين فى كل حاله من الحالات الخاصة تلدئ.

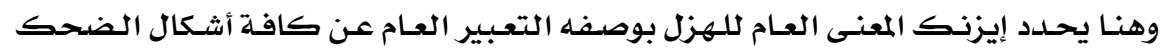

والفكاهه والنكتة والكوميديا هو اسهمـه الرئيسيـة." (1)

• ماهية التعبير

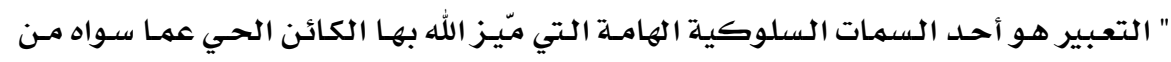

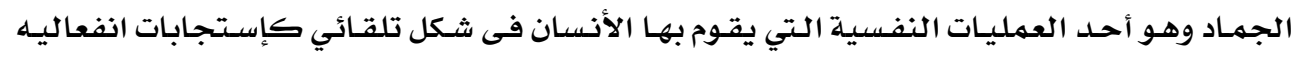

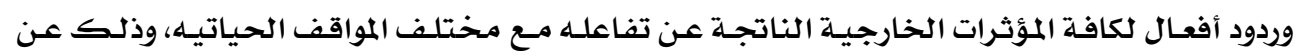

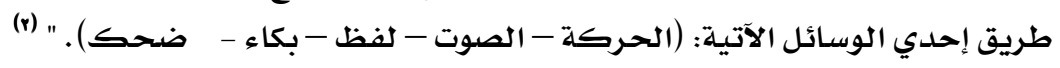

\section{• السمات التى تتصف بها التصويريه الهزليه:}

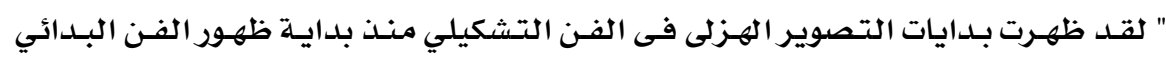

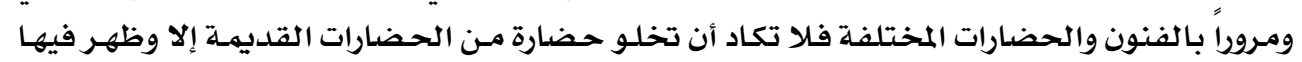

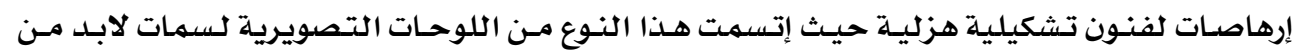

توافرها ومن أهم هذا السمات هي:

1- من حيث الموضوع:

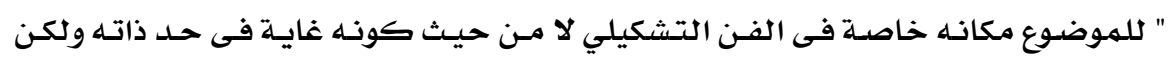

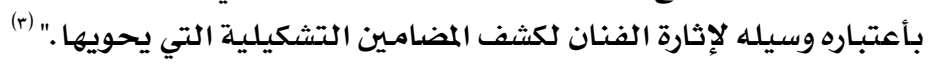

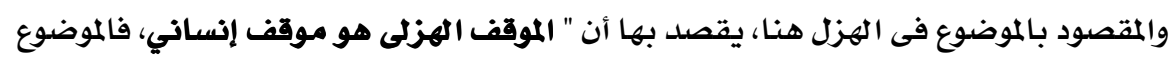

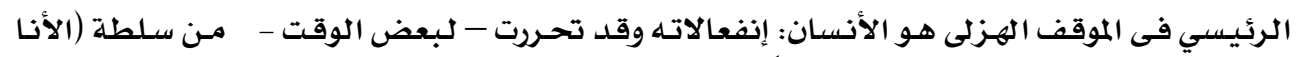

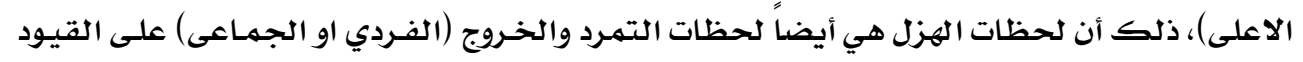

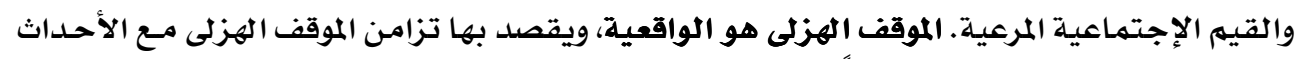

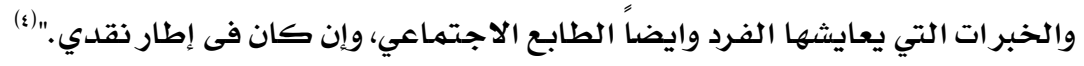

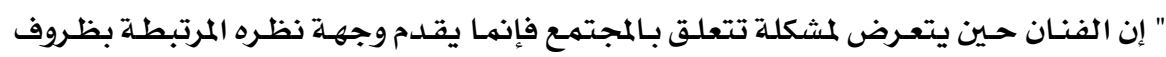

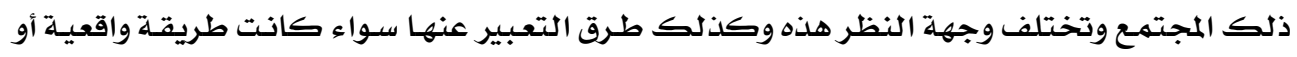

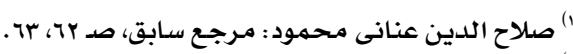

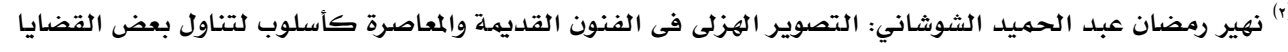

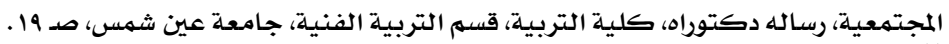

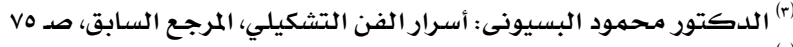

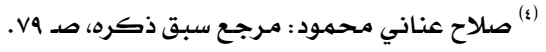




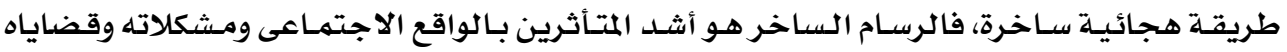

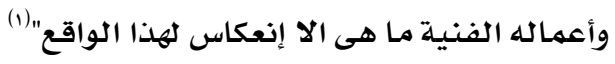

r- r من حيث التعبير:

" التعبير هو الإفصساح عن المعانى بلغة الشكل، وكل جسهر له معنى، والأجسسام حسين تتجـاوب

بعضها مـع بعض او تحتك او تولد معاني: هذه المعاني مـرتبطة بطبيعـة تلـك الأجسـام مـن حيـث إنها

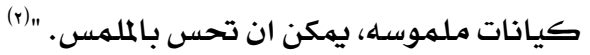
" تعمــ التعبيريـة الهزليـة ثـأنها شـأن التعبيريـة إلى التحريـف وتغـيير النسـب في الأثـكال الطبيعية ... ويكتسبـ الخط الخارجي المحلدد للأشكال، والفاصل بينهمـا أهميـة في التعبيريـة الهزليـة،

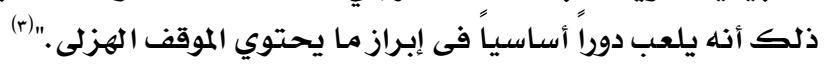

\section{r- من حيث التحريف}

" إتسـمت الاعمال التعبيرية الهزلية بشكل عام بتحريف وتغيير النسب لخلق علاقات جديده

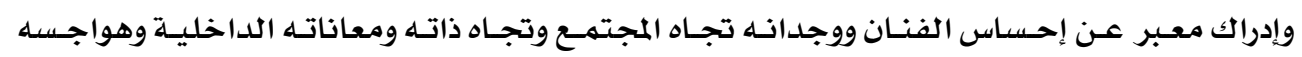
وإنفعالاته" (๕)

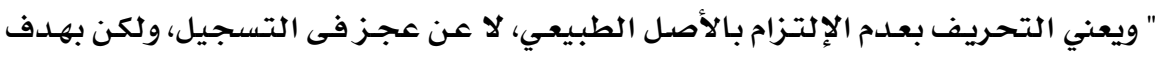

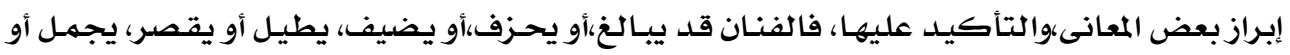

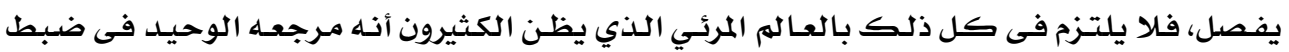
رؤيته الفنيـه،أي يظنون ان الحقيقة الفنية كامنـه فى الشئ، وما على الفنان إلا أن يستسلهم ويستجلها كهما هي،وعند ذلك يكون فى اعتقـادهم فنـانـا موهوبـا وهـهم يقيسون قدراتـه بههاراتـه فى النقل ودقـة المحاكاة. وفى الحقيقة أن العالم الخارجي لا يوجد فيـه مـن القيهم والمعـاني الفنيـة،إلا بقـد مـا ينفعل وهل به النفان" (ه) "وهـا هـي صـورة للفنـان (كـارل آبـل) * وتـسهمي (إسـتغاثة الحريـة) رقهم (r)، رسـم فيهـا وجـهـ

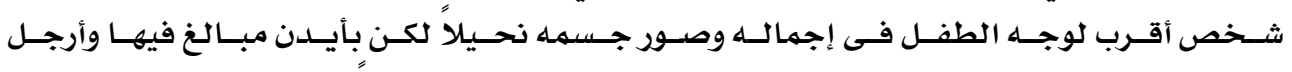
رمـزية .والدعوة للحرية تظهر فى التحريف الذي ينفجر بـه الوجـه صسارخاً داعيـا للخـلاص مـن القيود التي ملتكبل النفس البشريـة وتقف حجر عثرة فى طريق إنطلاقها ـ فالصورة ملتزمهة بنسبـة مـن العالم

(1) (نهير رمضان عبد الحميد الشوشاني: المرجع السابق، صـ م.

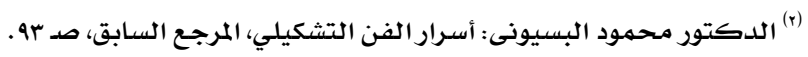

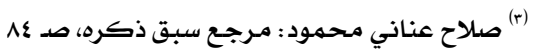

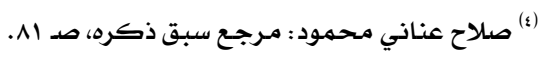

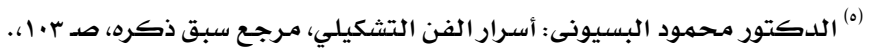

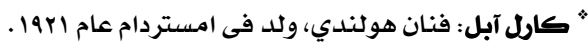




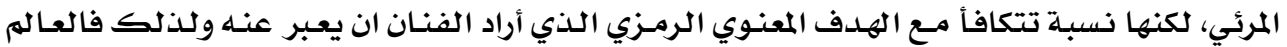

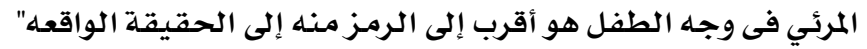

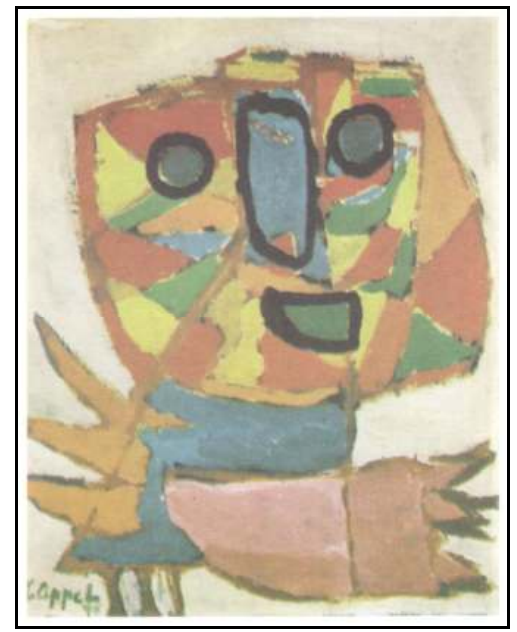

شكل ( r ): (استغاثة الحرية) لكارل ابل 1911 - صورة تحريفية رمزية لوجه أشبه بوجه الطفل المولود الذي

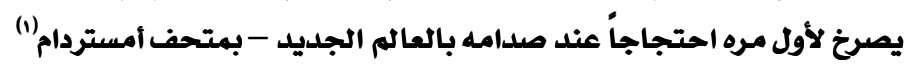
ثانياً: تاريخ التصوير الهزلى فى الفنوز القديمة مره احتواجية أ- التصوير الهزلى عند القدماء المصريين:

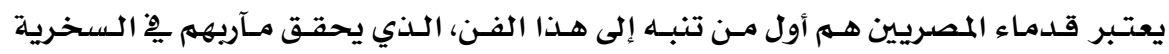

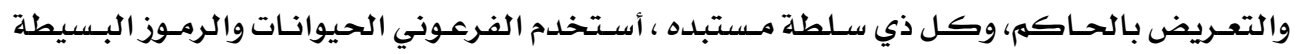

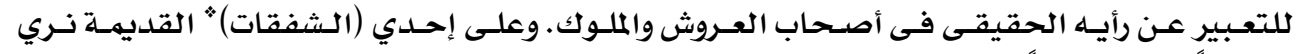

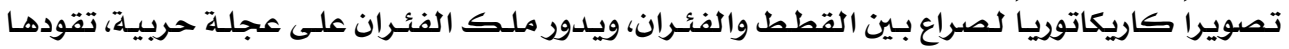

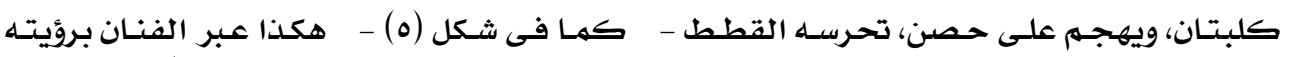

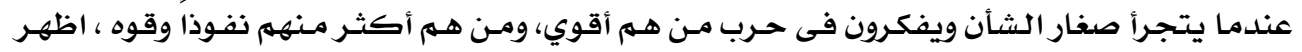

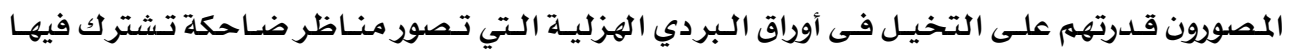

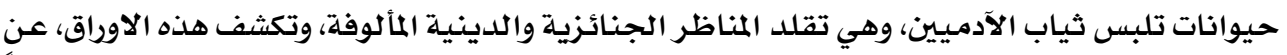

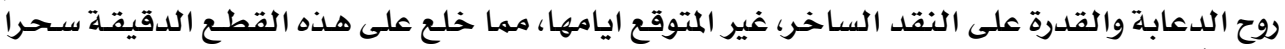

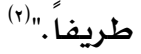

${ }^{(1)} \mathrm{http}: / /$ stedelijkindeoorlog.tumblr.com/

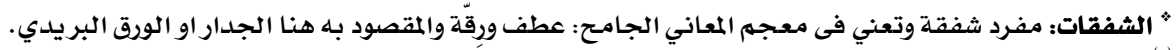

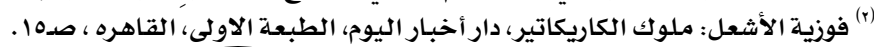


"ويوضـح المثـالين قــتين معسروفتين تم كتابتهـا مـع صــورتها، وفيهـا يتشبـه الحيوانـات

بـالانسـان وهي تهارس حـالات المرح والمزاج وفى هـذه المجهموعـة تجهـع أفراس النهـر الفاكهـه مـن شــره

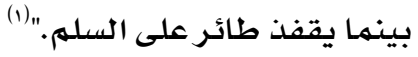

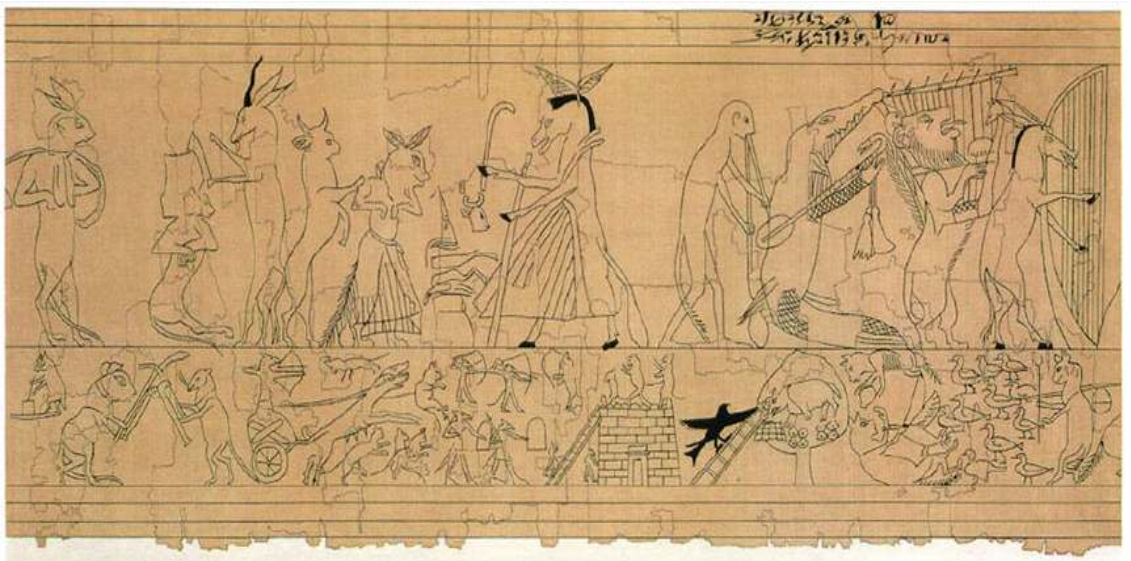

شكل (0) : صورة تهكمية وجلت فى قبر الملك رمسيس الخامس عام . .11 ق.م فى المتحف المصري

" كان الرسـام المصري القديهم يظهر عيوب مجتمعـه أملاً فى إصلاحسه فعلى إحلدي الشقفات

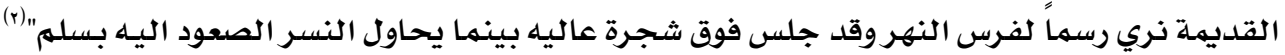
كما فى الشكل (7) التفصيلي (أ).

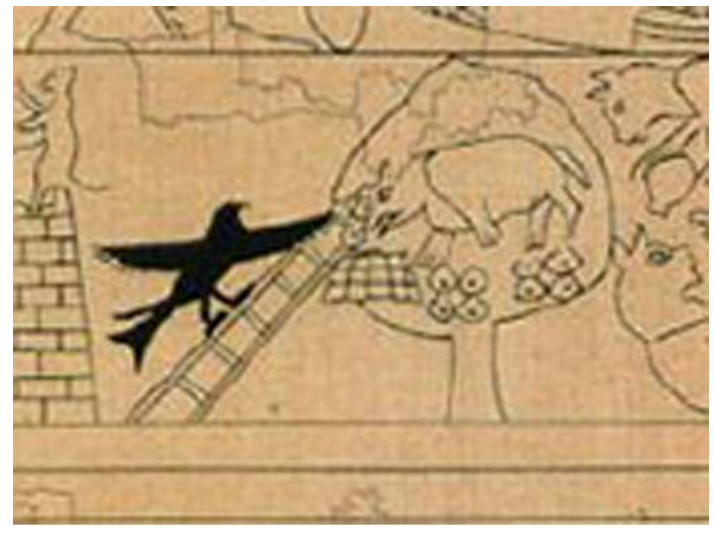

مفصل (أ) من الشكل (7) : صقر يحاول صعود شجرة بواسطة سلم

(1) Maarten J.Raven: Prisse D.Avennes (Atlas of Egyptian Art). University in Cairo press , page: 71

(r) فوزيـة الأشعل: ملوك الكاريكاتير، دار أخبار اليوم، الطبعة الاولى، القاهره ، صده . 
يعرف موضوع الصـراع بـين القطط والفـار مـن بعض رسـومات ولكن فقدات الحكايـة وتحفظ

هذا البردية الآن فى تورينو (إيطاليا ). كمها يِ الشكل رقم (v).

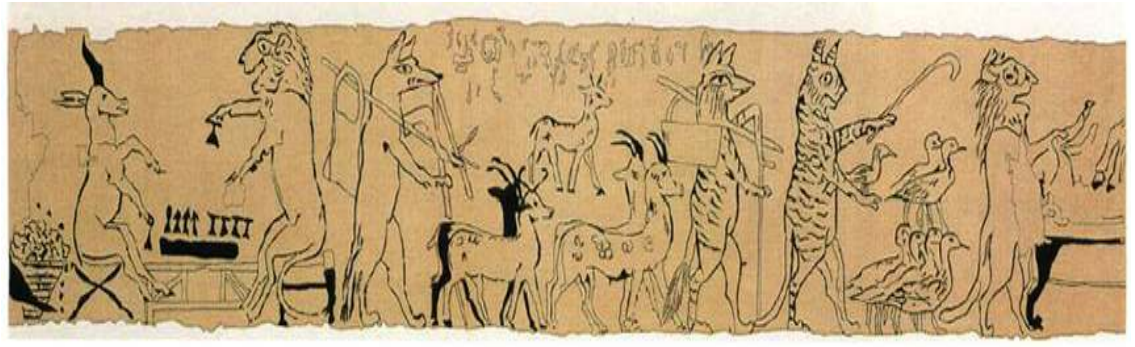

\section{شكل (v) : بردية بلندن من الدولة الحديثة بها رسوم هزلية}

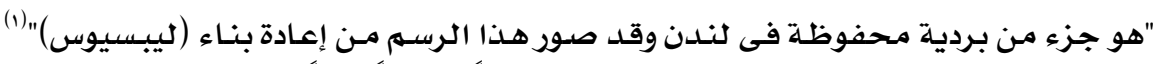

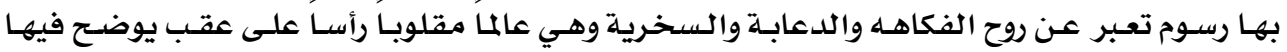

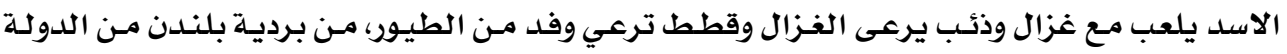

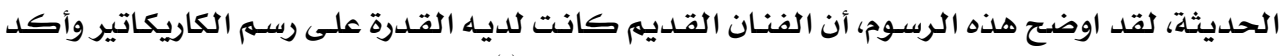

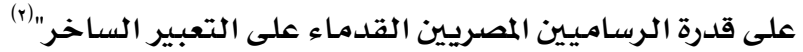

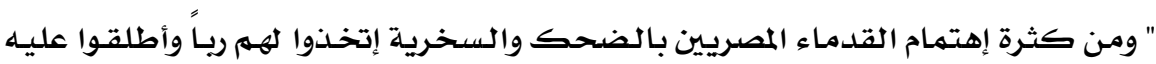
إسهم الآله (بس) * وهذا لاشك يعكس ولعهم الشلديد بالفكاهـ والضحك كما فى الشكل (ی) يوضـح

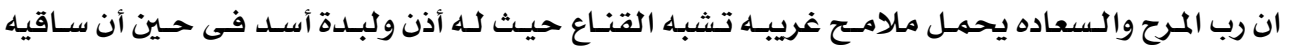

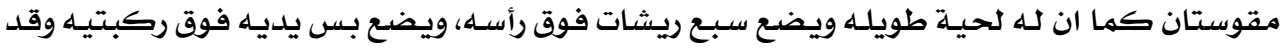

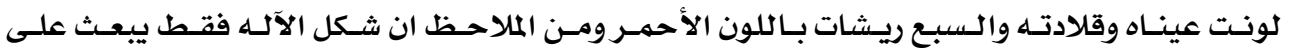

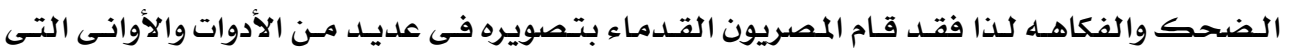

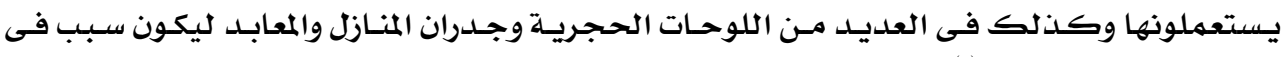
البهجة والسرور والمرح. "(r)

(1) Maarten J.Raven: Prisse D.Avennes (Atlas of Egyptian Art). University in Cairo press , page: 71

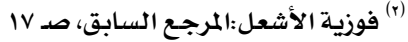

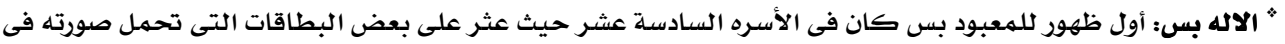

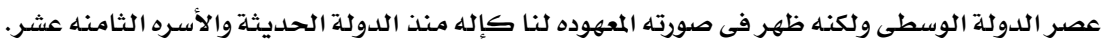

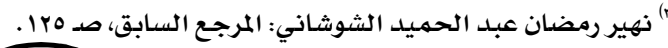




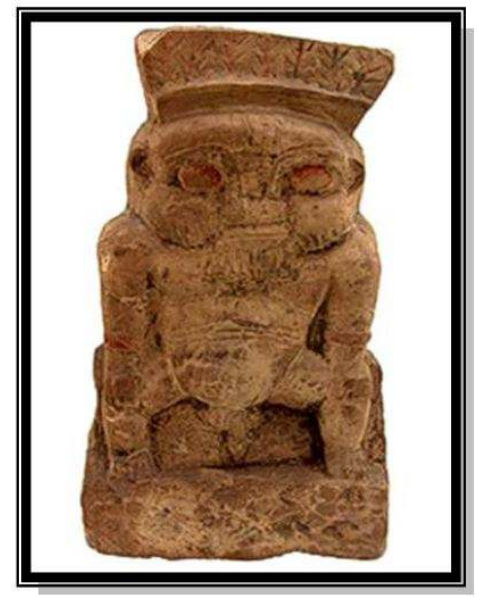

\section{شكل (^) : الآله بس اله الفكاهه والمرح}

\section{بـ - التصوير الهزلى فى فنون مابين النهريين:}

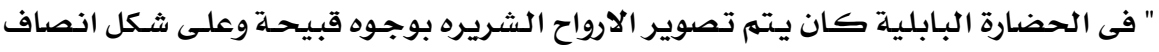

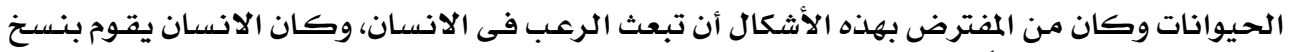

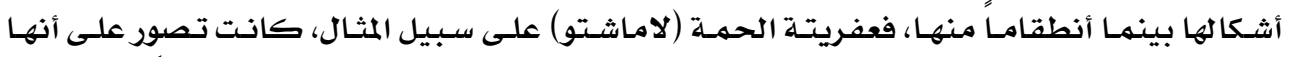

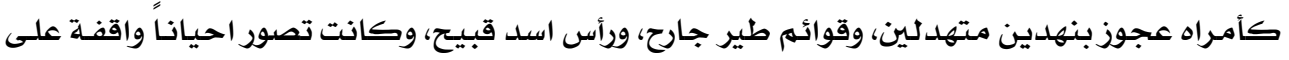

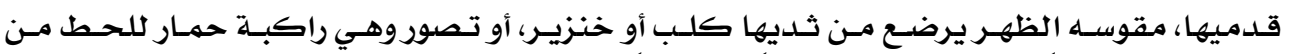

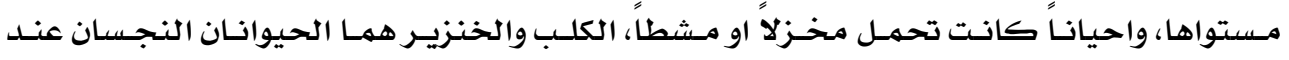

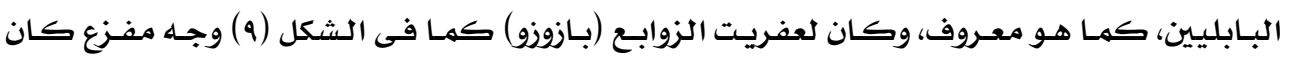

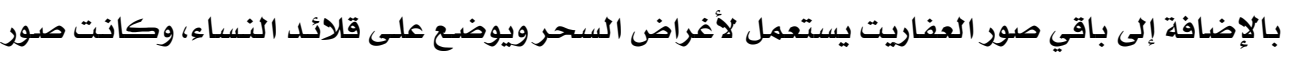

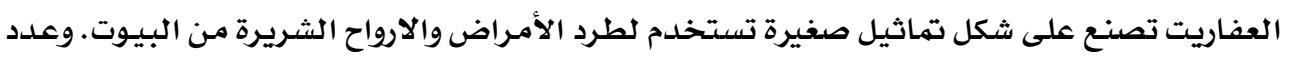

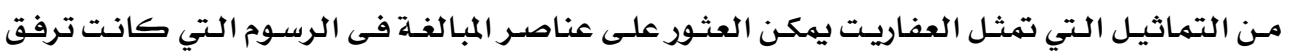

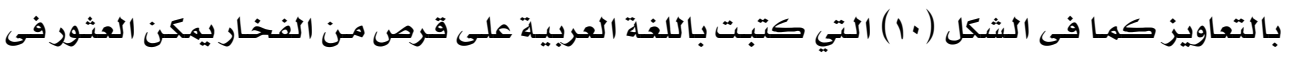

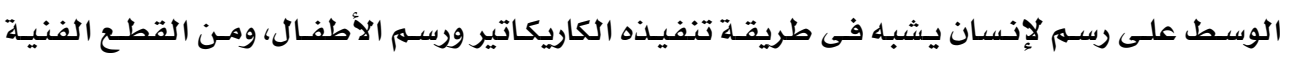

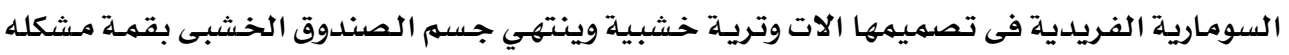

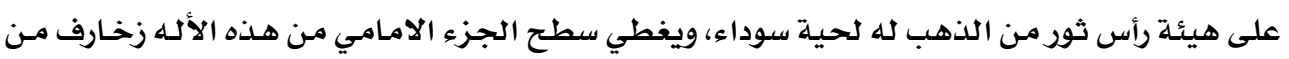

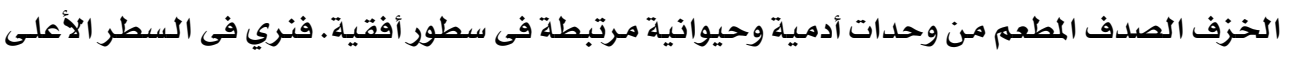

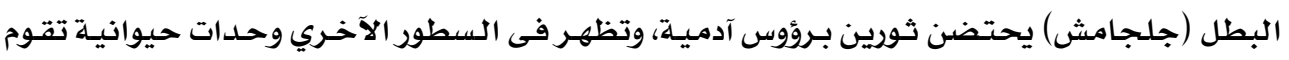

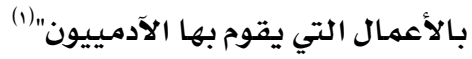

(') نهير رمضان عبد الحميد الثوشاني: مرجع سبق ذكره، صــ Y I I. 

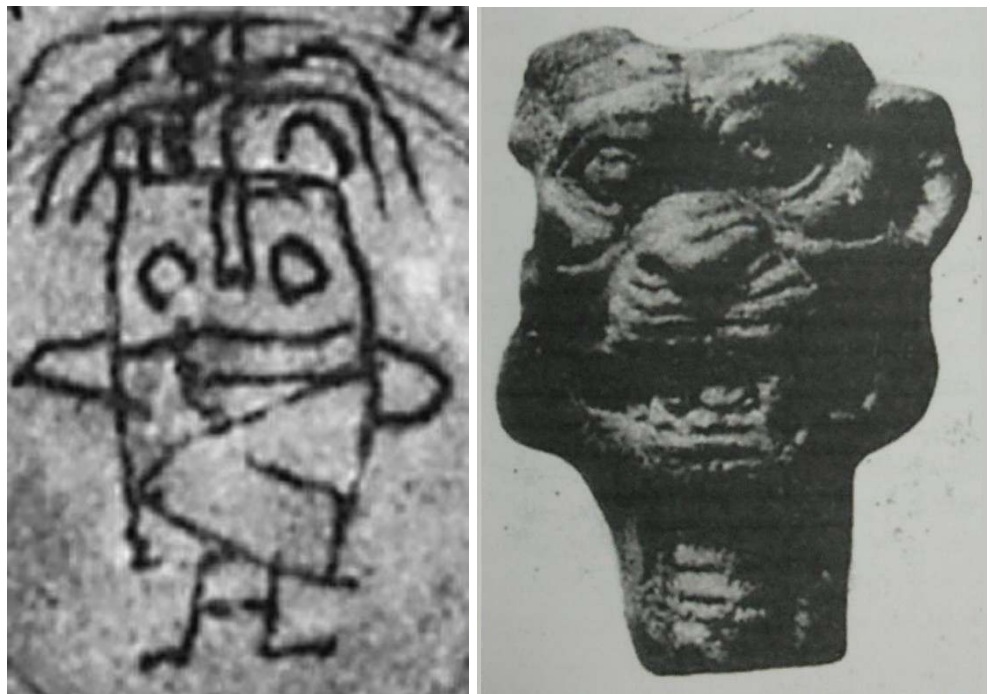

ثكل (9)، (ـ (1) : يوضح عفريت الحمي (لاماشتو) تعود للحضارة البابلية

جـ - التعبير الهزلي فى الفن اليوناني (الإغريقي)؛

لـو تحــثنـا عـن الهـزل عنـــ اليونـانيون فلابـــ مـن ذكـر (أريـستوفان) * " الـذي لم يبـق مـن

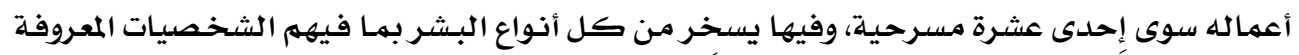

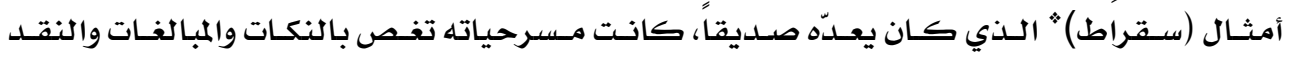

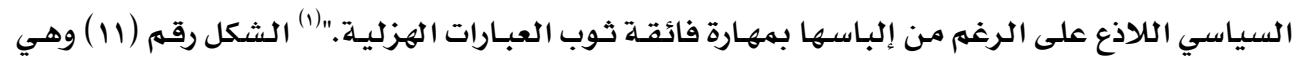
إحلدي أقنعة مسرح من الرقيق الأولي فى الكوميديا اليونانية.

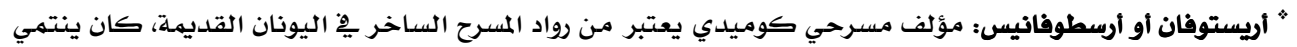

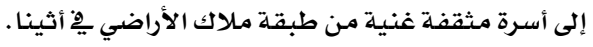

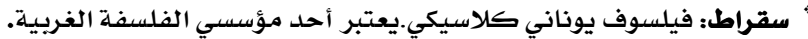
(1)https://ar.wikipedia.org/wiki/\%D8\%A3\%D8\%B1\%D9\%8A\%D8\%B3\%D8\%AA\%D 9\%88\%D9\%81\%D8\%A7\%D9\%86 


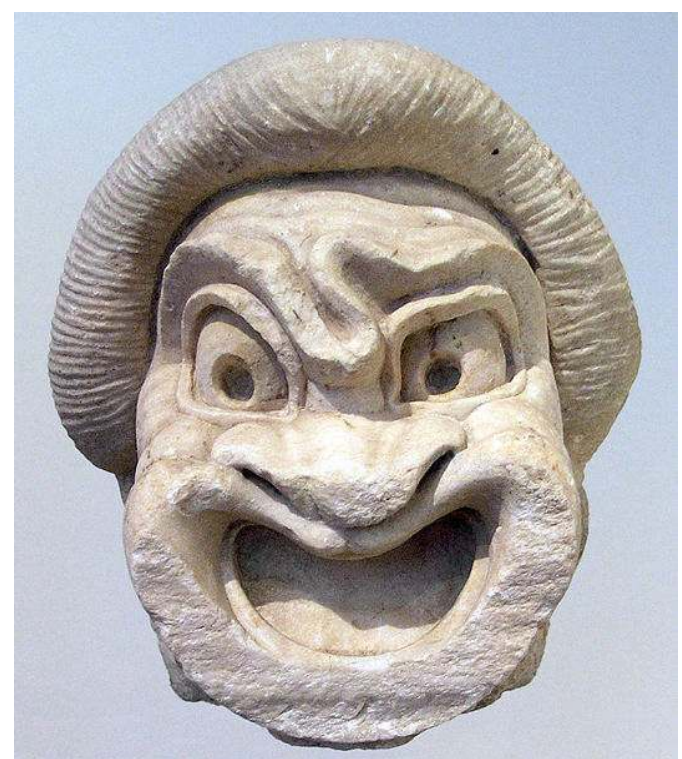

شكل (11): قناع مسرح من الرقيق الأولى يِ الكوميديا اليونانية، القرن الثاني قبل الميلاد، موجوده بالمتحف

\section{الأثري الوطني ـو أثينا}

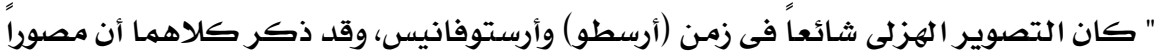

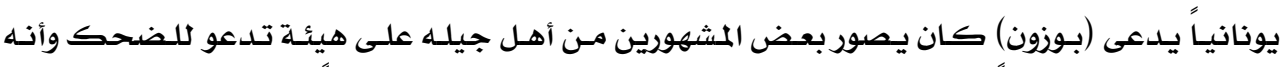

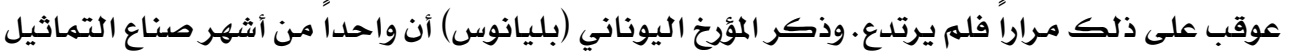

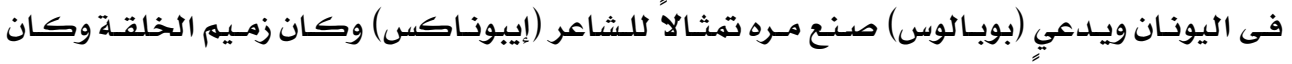

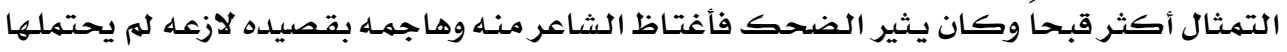
فأقدم على الأنتحار." (1) رابعاً : نماذج فنانين من الفرب تأثروا من فتون الحضارات القديمة فى أعمالهم التصويرية .

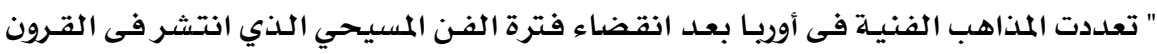

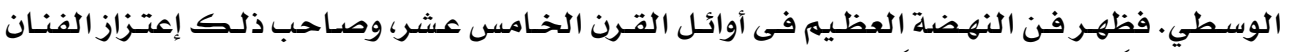

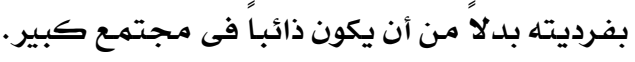

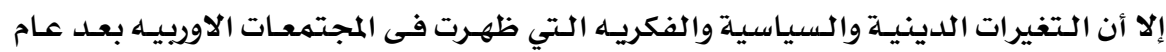

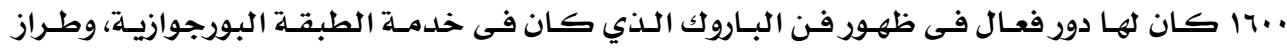

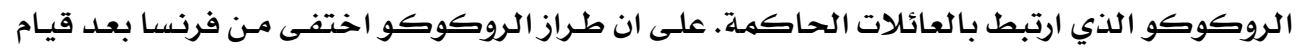

(') فوزية الأشعل: ملوك الكاريكاتير، مرجع سبق ذكره ، صــ.r. 
الثورة الفرنسيه عام IVA9 وظهر بها طراز فني استمدل مقوماتـه مـن الفنـون الإغريقيـة الرومانيـة عرف بأسهم الكلاسييه العائده" (1)

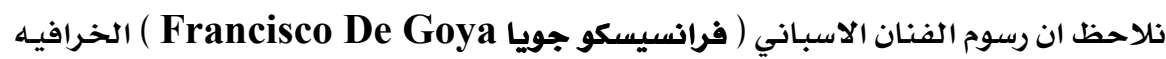

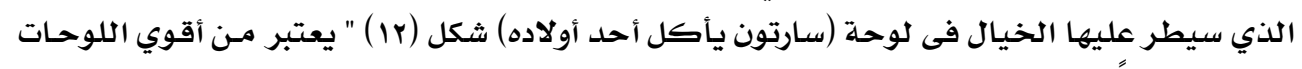

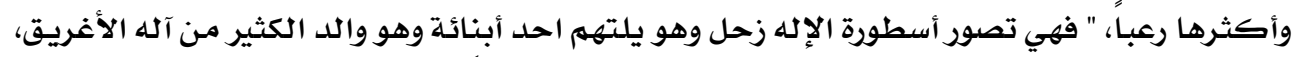

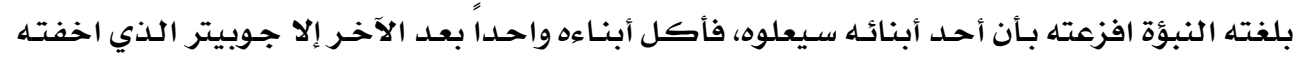

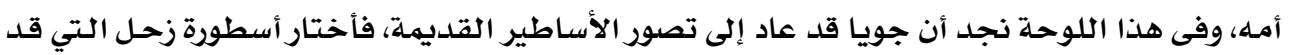

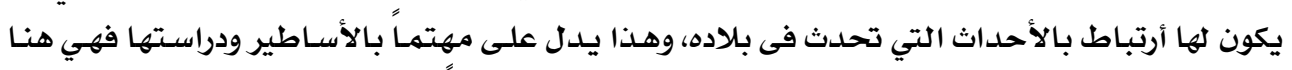

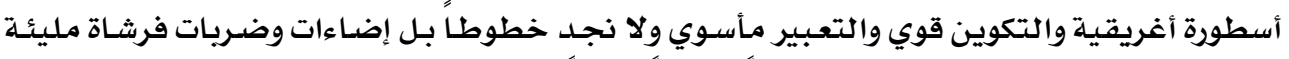

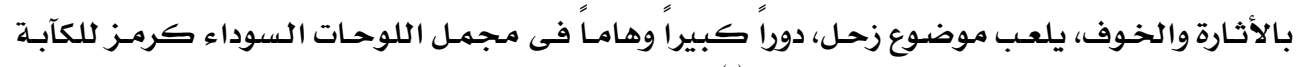

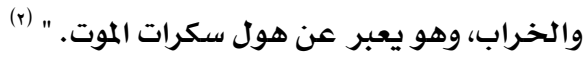

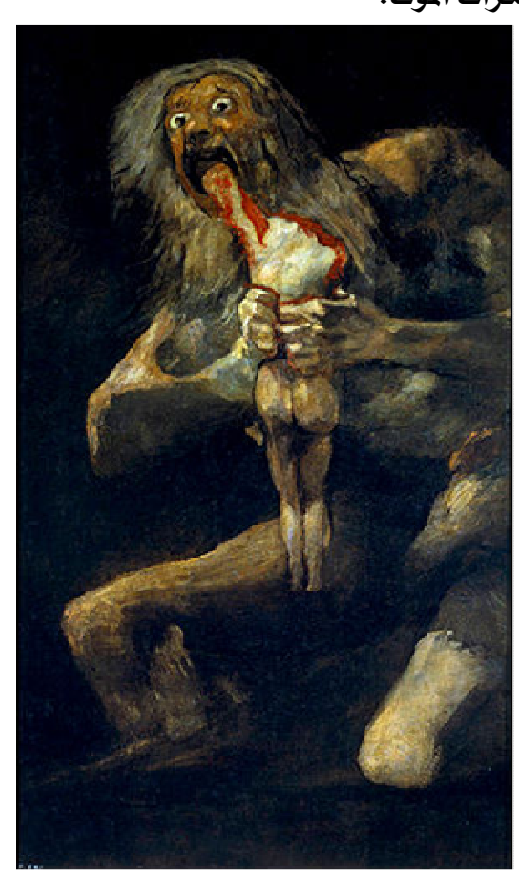

شكل (r) ): (سارتون يأكل أحد اولاده) فرانسيسكو جويا

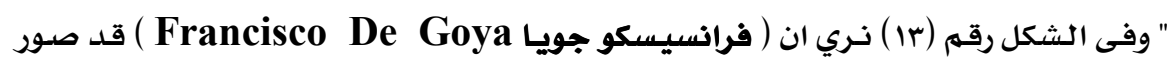

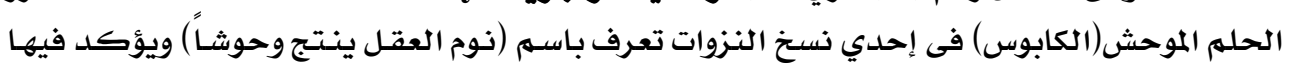

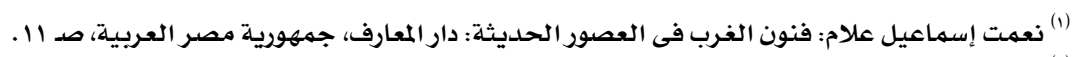

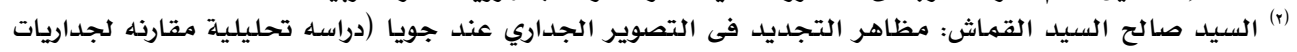

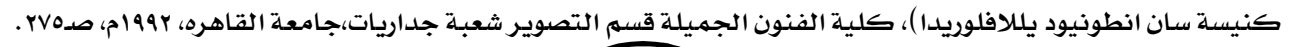


انه عندما يترك العقل الخيال فإنه ينتج وحوشاً وعندما يتحدان فأن الخيال يكون أبـاً للفنـون ومنبعـاً

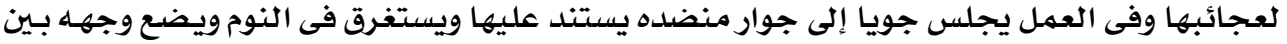

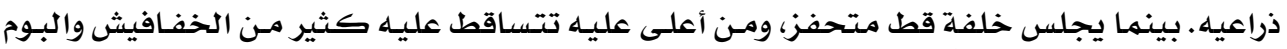

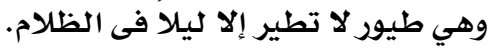

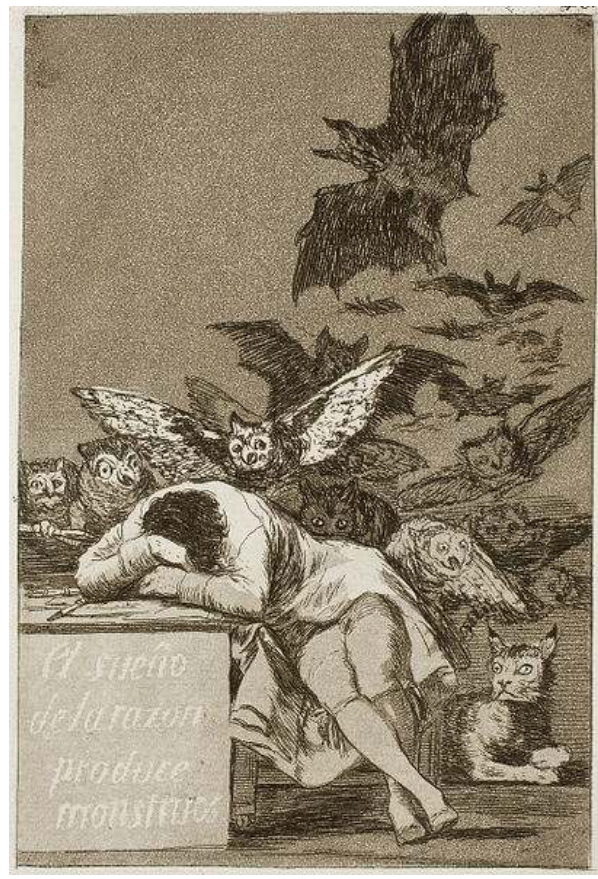

\section{شكل (r) ): نوم العقل ينتج وحوشاً، جويا}

" يعتبر القرنان الثامن عشر والتاسـع عشر من أزهي عصور التصوير الهزلى عامسة حتى أنـه

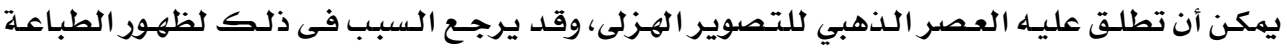

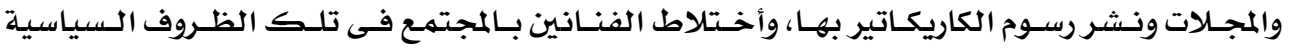

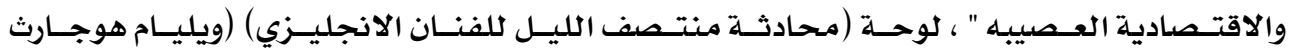

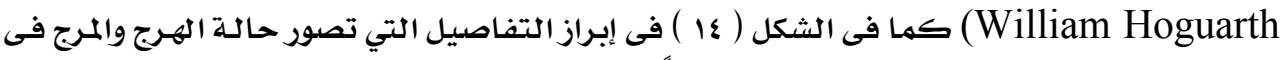

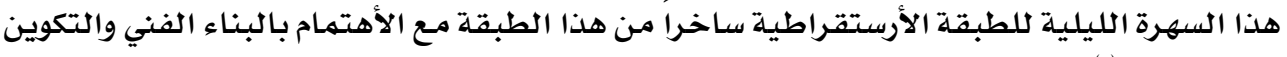




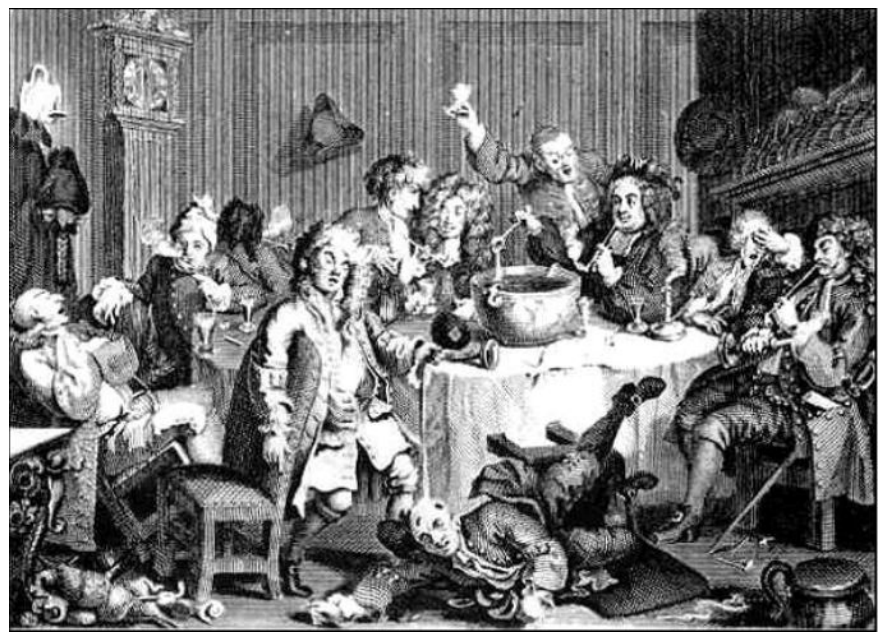

شكل (ع 1): محادثة منتصف الليل للفنان الانجليزي ( ويليام هوجارث William Hoguarth )

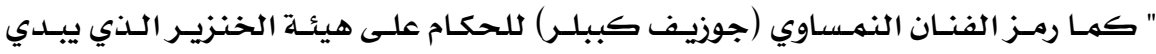

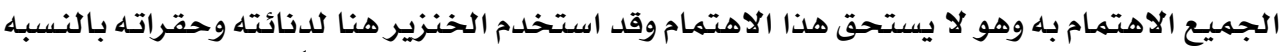

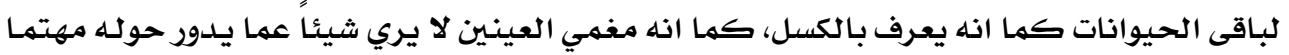

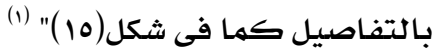

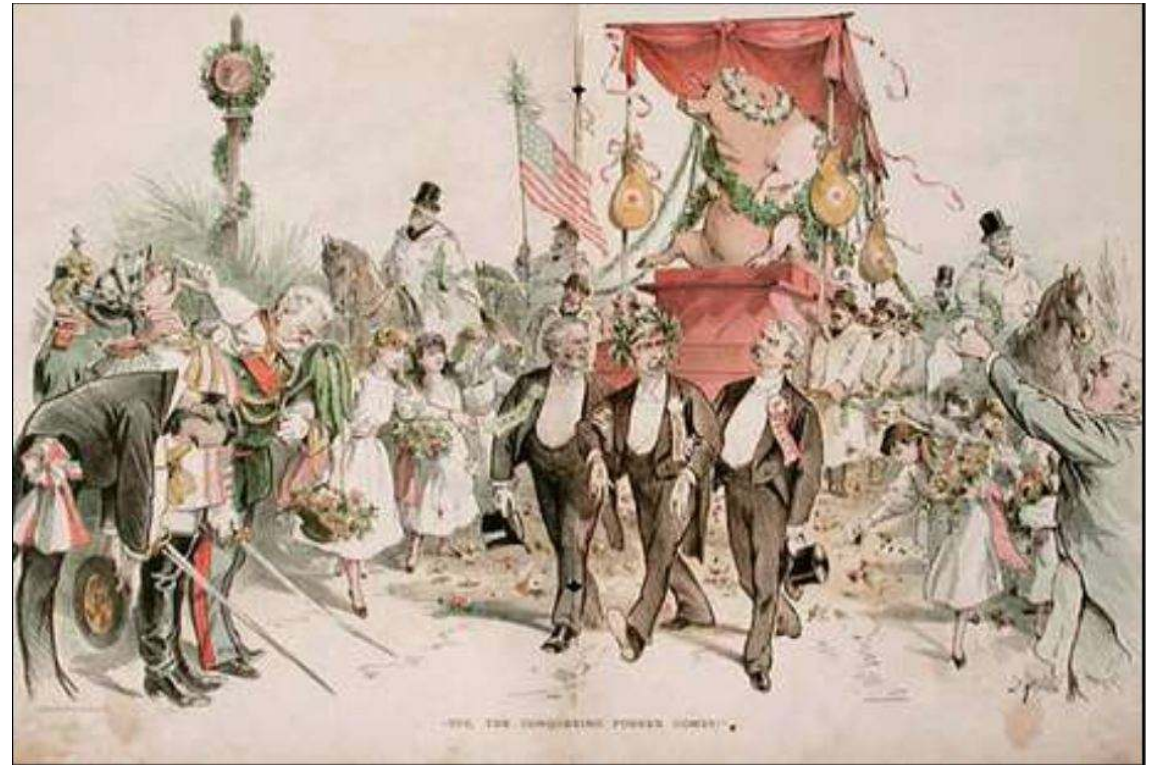

ثكل (10): فتح الخنزير الصغير للفنان النمساوي ( جوزيف كببلر )

(1) نهير رمضان عبد الحميد الشوشاني: المرجع السابق، صـ TV. 
" كان دومييـه متعدد المواهب، رسـاماً، كاريكاتورياً، ونحاتاً، ومصوراً ويعتبر - بعد جويا -

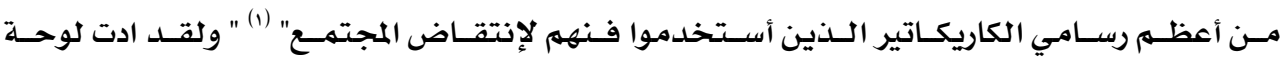
(Gargntua - - جارجانتو دخوله السجن حيث انه قام مـن خلالها بالتحريض على قتل الملك

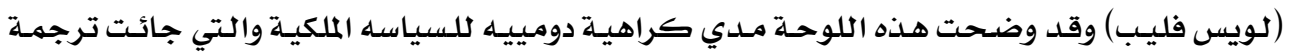

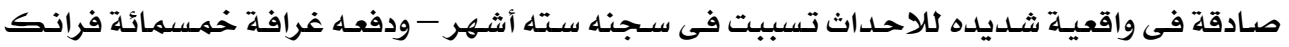
ويأتي اسهم اللوحة مستوحاه من اسهم عملاق شهير فى قصص الحكايـات الشعبية الأوربيـة فى العصور الوسطي ويعنى بـالعربية (البلعوم) وهو مشهور بشهيتـه الهائله وقد تحلدث عنسه الكثير من آدباء العصور الوسطي من امثال (سكسبير - رابلييـه) واللوحة تمثل لويس فليب كعملاق جالس فى استرخاء على

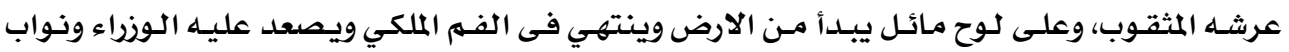
الشعب والاعيان ويصبون فى الفهم الملكي ذو الرأس الكمثري اجوله من الذهب والسـلال المحمولـه على ظهورهم وبعد ذلك يهضم (جارجـانتو) هذا كلـه ويخـرج مـن دبـره بـراءات النياشـين والاوسهـهـ " كهـا

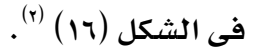

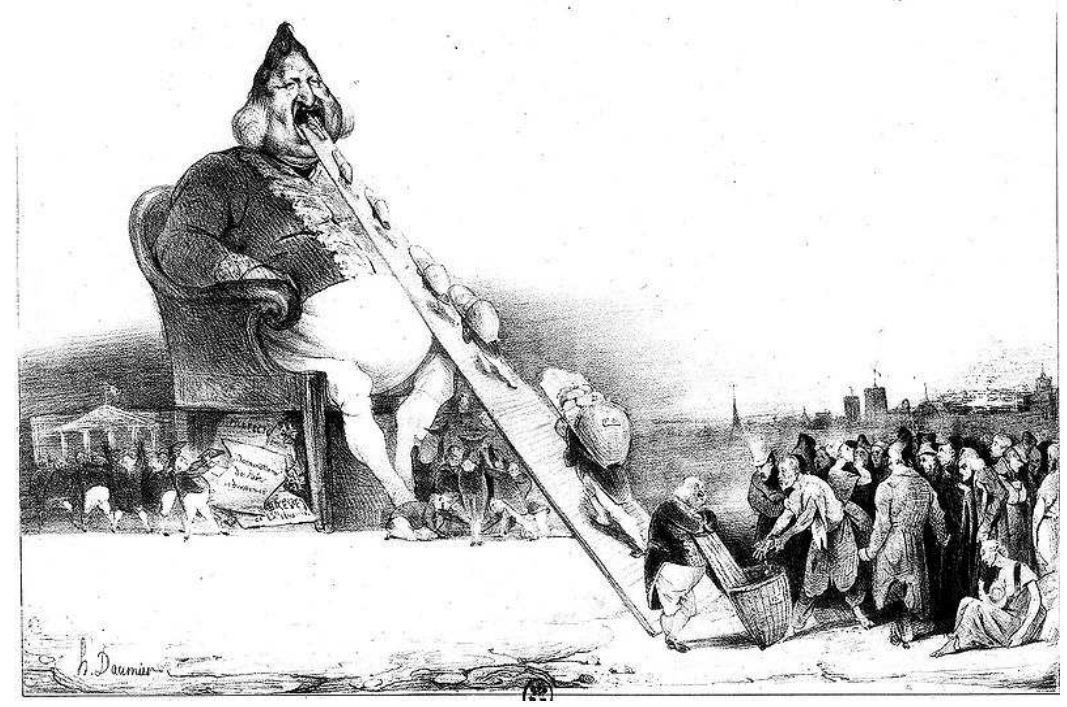

شكل: (17): (جارجانتوا) هنري دومييه عام ابه| معروضة فى المكتبة الوطنية، باريس(ب)

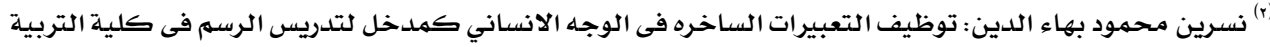

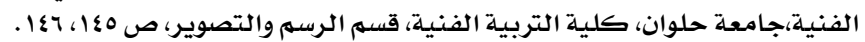
(3) http://www.wikiart.org/en/honore-daumier/gargantua-1831-1 


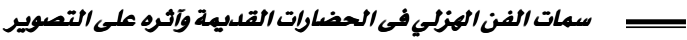 \\ النتائج والتوصيات : النتان : النتات \\ أولاً : النتائج:}

ينبغي ان نشير قبل أن نتعرض إلى ما انتهت اليه هذه الدراسة من نتائج إلى الحدود بشكل موجز لنقف على مجمل الظروف التي ساهمت بشكل عام فى تحقيق هذه النتائج.

\section{انتهت هذه الدراسة إلى نتائج أهمها:}

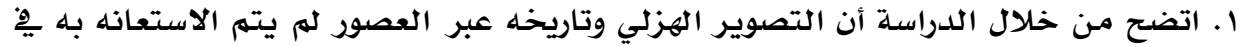

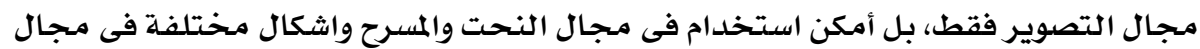

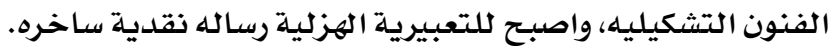

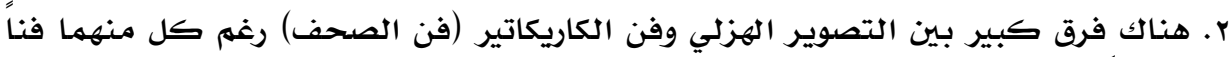
سـاخرا. r. وجود بعض الاعمال الفنية ضمن التعبيرية الهزلية ِِّ مراحل العصور القديمة كوسيلة

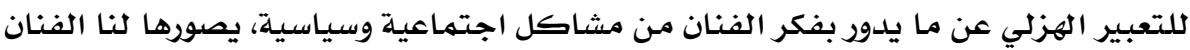

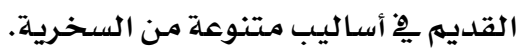

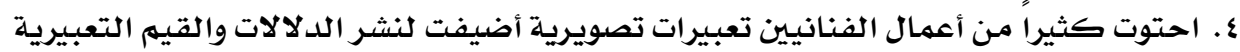

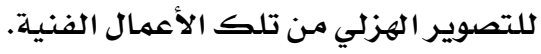
ثانياً: التوصيات:

ا. استكمال الدراسـات البحثية يِّ عمل أرشيف متكامل لأعمال الفنانيين الهزليين الرواد يِّ مصر

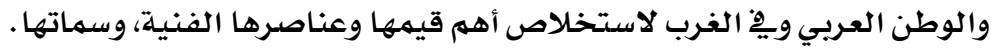

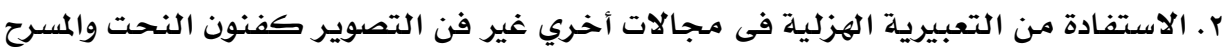
والأشغال الفنية وغيرها لزيادة الوعي بأهميتها.

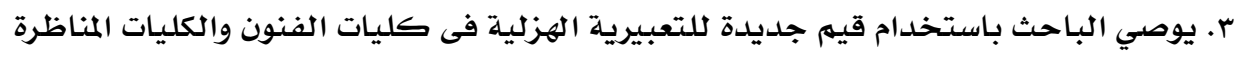

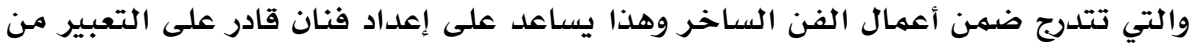

$$
\text { بعض المواقف المجتمعية. }
$$

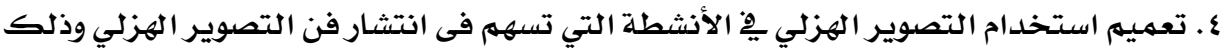

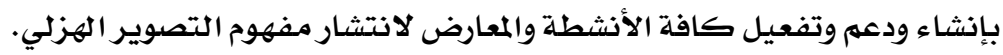


ا.السيد صالح السيد القماش: مظاهر التجديد فى التصوير الجداري عند جويا (دراسة تحليلية مقارنه

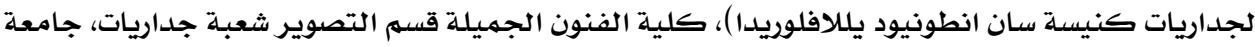

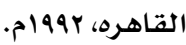
r r بلاح الدين عنانى محمود r.عادل مصطفى كامل: الكاريكاتير فى مصر، سلسلة الفنون، الهيئة المصرية العامة للكتاب، مكتبة الاسره .

$$
\text { ع ـ فوزية الأشعل: ملوك الكاريكاتير، دار أخبار اليوم، الطبعة الأولى، القاهرة. }
$$

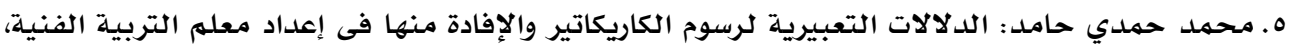

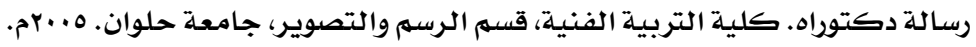

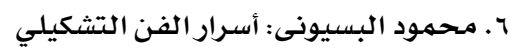

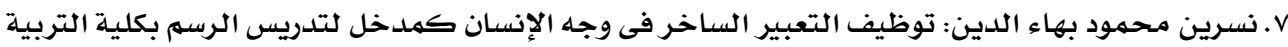

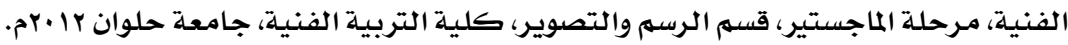

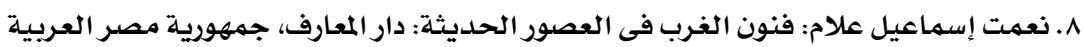

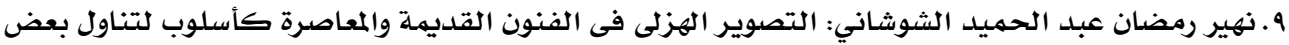

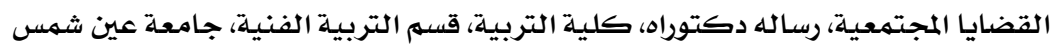

\section{ثانياً: المراجع الأجنبية:}

10. Maarten J.Raven: Prisse D.Avennes (Atlas of Egyptian Art). University in Cairo press , page: 71

\section{ثالثًا: مراجع شبكة المعلومات الدولية (الأنترنت):}

11. http://www.almaany.com/quran/86/14/3/\#.V14QOr-6bDc

12. http://library.islamweb.net/newlibrary/display_book.php?idfrom=8653\&idto= $8653 \&$ bk_no $=122 \& \mathrm{ID}=8665$

13. http://stedelijkindeoorlog.tumblr.com/

14. https://www.ward2u.com/showthread.php?t=22836

15. https://ar.wikipedia.org/wiki/\%D9\%87\%D8\%A7\%D9\%86\%D8\%B2_\%D8\%A 2\%D9\%8A\%D8\%B2\%D9\%86\%D9\%83

16. http://www.wikiart.org/en/honore-daumier/gargantua-1831-1 


\section{Features of comic art in ancient civilizations and their effects on modern painting}

\section{Abstract}

Psychologists and poets linked perception ways with axes of comic sense starting with comedy and humor, and artists have been influenced by them from various ancient civilizations such as comic art, caricature and other arts that contain irony of everyday situations (either social or political ones) that appear around the artist. This paper presents comic art in ancient civilizations: its stages, vocabulary, methods of composition and inspired concepts. This study contains the following items:

1. Introduction (Research Problem - Objectives - Importance Limitations - Methodology)

2. Concepts, terms and definitions.

3 .The artistic features of comic art.

4. Evolution of comic photography in ancient art.

- Comic art among the ancient Egyptians.

- Comic art in the arts between the two rivers.

- Comic art of Greek art.

5. Models of artists from the West influenced by the arts of ancient civilizations in their works of photography.

6 . Conclusions and recommendations. 